\title{
Human Trafficking in North Sulawesi Indonesia
}

\author{
Ruth Sriana Umbase, Grystin Djein Sumilat
}

\begin{abstract}
The aims of this research are to identify the factors that cause human trafficking, to describe the map of origin region and destination of delivery, to analyze the modes used by the traffickers. The method used is the Qualitative Descriptive Method. The results showed that there were seven main factors causing human trafficking in North Sulawesi. Those were lifestyle, lack of knowledge and capacity, potential employability as commercial sex workers, demand of commercial sex workers, youth marriage and limited employment in formal sectors and secullarism. Most of the victims came from Manado City, Minahasa, South Minahasa and North Minahasa Regency. The largest destination areas of the victims were Papua, West Papua, Southeast Sulawesi and Batam (the Province of Riau Islands). The modes used by the perpetrators are persuading victims to work outside the area with high incomes, cheated with debt bondage, offering scholarship programs, adopted as children, fraudulent and abducting. The efforts that need to be done to eliminate human trafficking are changing the lifestyles from consumptive to productive by increasing self-resilience (changing the paradigm of thinking to be realistic and not regarding material wealth as a source of self-esteem or avoiding hedonism) and improving self-capacity through continuous knowledge enhancement. Local governments need to enlighten the publics through various programs/activities such as socialization with emphasis on human trafficking modes, to train of members of the task force on prevention of human traffics, to cooperate and to form partnerships with other institutions and local/regional governments, to build cooperation on the prevention and handling of human traffics with non-government institutions, to break the links of sexual trafficking and other types of unlawful businesses, to prevent young marriages to stimulate job creations, especially in the formal sectors and to increase the roles of parents and education institutions.
\end{abstract}

Keywords: Human Traffiking; Lifestyle; Sexual Commercial and Exploitation.

\section{INTRODUCTION}

Human Trafficking is a serious problem faced by the Indonesian people especially in North Sulawesi. The biggest victims of trafficking are women and children; Therefore, the ASEAN countries have agreed on the ASEAN Convention against Trafficking in Persons Especially Women and Children (ACTIP) on 21 November 2015. The objective of ACTIP is to achieve a comprehensive approach to the issue of People's Trade Crimes through the 4P concept, namely: Protection, Prevention, Prosecution and Partnership through cooperation among ASEAN members. (1).

Revised Manuscript Received on September 22, 2019.

Ruth Sriana Umbase, Universitas Negeri Manado Tondano Indonesia. ruthumbase@unima.ac.id.

Grystin Djein Sumilat, Universitas Negeri Manado Tondano Indonesia grystin_sumilat@unima.ac.id.
Trafficking of women and children in Indonesia has been rated very apprehensive now. The United Nations Council (UN) incorporated Indonesia into a country's poor level in dealing with the social issues of trafficking in persons. Indonesia is also classified as a standard state III which means that Indonesia is considered not serious in handling trafficking of women and children. There are several categories so that a country can be classified in standard III for the problem of women and children. First, the country is not serious in dealing with trafficking in women and children. Secondly, the country has no laws governing trafficking of women and children. Third, the country is a transit country and a sender for trafficking of women and children. And fourth, the country has no data about how many children and women are trafficked.

Although the State of the Republic of Indonesia already has Law No.21 of 2007 on the Eradication of The Criminal Action of Human Trafficking (Undang-Undang No. 21 Tahun 2007 tentang Tindak Pidana Perdagangan Orang), even long before the Act is established; North Sulawesi Province already has Regional Regulation No. 1 of 2004 on Prevention and Eradication of Human Trafficking in Especially Women and Children (Peraturan Daerah No. 1 Tahun 2004 tentang Pencegahan dan Pemberantasan Perdagangan Manusia khususnya Perempuan dan Anak), but the occurrence of human trafficking cases in North Sulawesi is still a concern for many parties. The aims of this study are: to identify the factors that cause human trafficking; explain the origin and destination of trafficking in persons; analyze the modes used by traffickers to recruit victims; and find solutions to be recommended in solving human trafficking problems in North Sulawesi Indonesia.

\section{LITERATURE REVIEW}

Historically, human trafficking has been carried out since the idea of mastery and slavery by a group of people in order to expand power in the domestic level of ethnic groups (ethnic or ethnic groups) as well as in the broader power organization in the category of a nation-state, . The main motive is to gain power in controlling / governing and utilizing the controlled people for the sake of the powerful. But along with the awareness and understanding of human rights, humanists and human rights advocates have protested against bad practices in exploiting people as a form of crime against humanity.

The tragedy of human trafficking began to emerge and be debated after an awareness of humanism, freedom, democracy and human rights.

\section{Published By:}

Blue Eyes Intelligence Engineering 
In Preamble of The Constitution states Republic of Indonesia (Undang-Undang Dasar 1945) that "freedom is the right of all nations and hence the occupation must be abolished from the face of this earth. The colonies meant here are multi-dimensional. Colonial meaningful also as planned and systematic action aimed at making a certain person or group of people become "helpless" in various aspects and subject completely to strong party. Under these circumstances, the powerless party can be exploited and even exploited by a strong party for its own interests or the interests of the group.

In Act Number 21 of 2007 concerning the Eradication of Criminal Action Human Trafficking in Persons, (Undang-Undang No. 21 Tahun 2007 tentang Tindak Pidana Perdagangan Orang), Article 1 Paragraph (1) provides that Trafficking in Persons is an act of recruitment, transportation, shelter, transfer, transfer or acceptance of a person under threat of violence. The use of violence, abduction, imprisonment, fraud, abuse of power or vulnerable positions, debt bondage or benefits, so obtaining the consent of the person in control of the other, whether within or outside the country, for the purpose exploitation or exploitation of people (3)

In the definition of human trafficking the person can be identified two main modes namely the use of violence and fraud. Traffikers can use various forms of violence and deception in accordance with the position and condition of vulnerable someone who was in a state of powerless mentally and spiritually. These vulnerable groups are mostly women and children who are weak in the face of the reality of life, weak in the face of various social, cultural, economic and other pressures that are easily influenced, easy to believe and persuaded by traffickers.

According to Sulistyowati Irianto that "trafficking patterns of people, especially women and children have existed since the time of slavery and can be found in the form of prostitution and cheap labor now." (4)

The need in the medical field through various transplantation techniques of human organs to replace the organ that has been damaged/hence the potential for the sale of human organs, can happen everytime and everywhere it is needed. In ignorance, weakness, and even economic vulnerability, a person may sell his organs or someone may be deceived or tricked by someone else to trade.

\section{METHODOLOGY/MATERIALS}

The Research Method used is Descriptive Qualitative Research Methods and Data Collection Techniques used are Documentation, Observation and Interviews. Data analysis was performed with Interactive Data Analysis Technique. (2) . The source of data are victims of trafficking in North Sulawesi Indonesia, Women and Child Protection Unit at Police office in Manado North Sulawesi Indonesia, Centre of Integrated Service Protection on women and child of North Sulawesi Province (Pusat Pelayanan Terpadu Perlindungan Perempuan dan Anak).

\section{RESULTS AND FINDINGS}

Human trafficking in North Sulawesi has occurred long before the enactment of Regional Regulation No. 1 of 2004. Although historically, there is still a need to study the facts about the history of human trafficking in North Sulawesi, but the emergence of the regional regulation is an evidence of the concerns of the government and communities in the province of North Sulawesi against the rise of human trafficking and the adverse consequences it causes.

The research results on Trafficking practices in North Sulawesi shows that the victims are those who are powerless both to themselves (intern) and to others outside themselves (external). The factors causing the selflessness so trapped in human trafficking are: 1 . Weak concept of self in perceiving the existence of life based on noble character. In this context, lifestyle is not defined and built on the principle of life of noble character, but rather more determined by the social measures based on the material as a source of quality one's self. The quality of one's self is measured by the material ownership and pleasure enjoyed by the abundance of the material. There is a social fact in North Sulawesi that if a person has a wealth of material abundance then it shows that the person is blessed by God. One can boast both spiritually and materially with an abundance of material possessions. Therefore, many people are then easily deceived because of helplessness in perceiving and building self-concept or self-image based on the principles of beauty of the character (noble character). This self-concept is an abstraction of thought which then influences the way of attitude, kneeling, and acting. From here it can be traced to the formation of a habituated hedonic lifestyle, pleasurable, lulled in pleasure and self-esteem over the abundance of matter considered a source of happiness. 2. Lack of knowledge and capacity to be able to understand and reject the deceptions, traps, persuasions of traffickers. Traffickers who have high knowledge in deceiving, persuade and even trap potential victims is a strong group both in terms of knowledge, attitude and communication skills and use all aspects that can be utilized including money and other materials to recruit potential victims. From statements submitted by the victims, they have been deceived and deceived by persuasion, promise and debt traps, the kindness done by traffickers turns into the threat of violence if their wishes are not met. In addition, the deceived victims lack the realistic knowledge and skills to survive realistically to work in the jobs available around them, such as farming, working in the informal sector, working as a household assistant, preferring instead to choose "prestigious", easy to do and make more money. 3. Potential to trade in the field of commercial sex because it physically has a beautiful face and sexy body. The opportunity to be employed as a comforting woman is sufficiently available for "Manado Women" and this opportunity has been targeted by traffickers to be exploited. 4. Marriage at a young age due to promiscuity. 5. Limited work on the formal sector. 
6. Less concerned about religious values, prioritizing material interests as evidence that a person is blessed by God. The influence of globalization and modern religious lifestyles that prioritizes celebration rather than character building, contemplation for self-evaluation and conversion has eroded the spiritual, then religious values become more pragmatic and secular. Adrienne Sanders calls it such a condition as a result of the ideology of neo-liberalism in the global era (5)

From an external perspective the widespread business of pornography and the demand for workers in the entertainment and prostitution business has caused women and adolescents to be vulnerable to trafficking. Poverty, the attractiveness of luxury of life, the weakness of law enforcement, sectoral egoism and partial development have created weaknesses in coordination, collaboration and synergy that have opened the gap for exploitation by traffikers.

The origin of trafficking victims are from Minahasa Regency, South Minahasa, Tomohon City, North Minahasa, Manado City, and Bolaang Mongondow Regency. The destination areas are Papua, Kendari, Bali, Jakarta, and Batam and other major cities.

The main mode used by the traffickers is fraud and violence. Fraud is committed with persuasion to work outside areas with high salaries, if victims are still sitting on the bench of education they are persuaded to be included as cultural ambassadors, beauty contests, modeling, even offers to get scholarships and work overseas. The most common mode used by the traffickers is using debt traps through money loan offerings, purchasing clothing, jewelry, cosmetics and other items on credit. If it cannot pay the debt then they used the threat of violence until the murder, so that those who have owed the surrender unconditionally to the traffickers.

\section{Conclusion}

The factors behind human trafficking in North Sulawesi can be categorized into two factors: internal and external. Internal factors are powerlessness in the face of persuasion and trafficking tricks. The powerlessness includes: the inability to be realistic in organizing consumptive and hedonic lifestyles. Weakness in rejecting debt traps and curbing the desire to not owe and seek other alternatives to meet the needs of life. Lack of knowledge about trafficking. Physically potential to be traded as commercial sex workers. Less concerned about religious values but likes to self-image as a person who is blessed by God with wealth.

Area of origin and destination. The origin of the victims of trafficking are Minahasa, Minahasa Selatan, Tomohon and Minahasa Utara. There are also those from Bolaang Mongondow district. The destination areas are Papua, Kendari, Bali, Jakarta, and Batam and other major cities.

The mode of trafficking in persons, the mode used by perpetrators is fraud and violence. Based on the causal factor, mode, origin and destination of trafficking, it can be suggested to eliminate the cause factor by educating, changing the paradigm of thinking in building self-concept of society about quality standard of living especially in target area of trafficking so that people will not be easily tempted by easy way to earn abundant money, self-esteem is not solely determined by matter but by a lifestyle that has a noble character; increased knowledge and capacity, and life skills especially for women and adolescents through formal, non-formal and informal education institutions; break the commercial sex trade chain; prevent marriage at a young age; create jobs and increase piety to God Almighty. Therefore, enhancing the role of government in policy-making until the implementation of programs and activities to stop human trafficking should be carried out seriously and all parties involved in it can execute it with full responsibility. Optimizing Gugus Tugas Tindak Pidana Perdagangan Orang (Task Force of Elimination of Human Trafficking) roles and responsibilities that have been formed even encourage the community to establish a container for prevention of human trafficking in accordance with local wisdom owned by the community, especially at the village level which can synergistically integrated with other task forces such as Pembinaan Kesejahteraan Keluarga (PKK- Founding of Family Welfare), Lembaga Pemberdayaan Masyarakat (LPM-Institutions of Society Empowerment), Community Watch (CW) and others.

\section{REFERENCES}

[1] Kementerian Luar Negeri RI, Indonesia Ratifikasi RUU tentang Pengesahan ASEAN Convention against Trafficking in Persons, Especially Women and Children. https://www.kemlu.go.id. Accessed, June 202018.

[2] Huberman, A .Michael and Matthew B. Miles, Data Management and Handbook of Qualitative Research,ThousandOak, California: Sage Publications, Inc. 1994.

[3] Jenna,Maack, Sex Trafficking in Southeast Asia: The need for a Victim-Centered Perspective http://ufsacademy.org/wp-content/uploads/2011/02/maack-Sex-Traffic king-in Southeast-Asia.pdf.

[4] Sulistyowati Irianto, Perdagangan Perempuan dalam Jaringan Narkoba, Jakarta:Yayasan Obor Indonesia, 2005.

[5] Adrienne Sanders, Sex Trafficking in Southeast Asia: How Neo-Liberalism Has Bolstered the Global Sex Trade. http://web.uvic.ca/-onpol/spring2012/one\%20-\%20Adrienne.Pdf.

\section{AUTHORS PROFILE}

My name is Ruth Sriana Umbase, I am associated with Universitas Negeri Manado Tondano Indonesia.my area of interest is social sciences

Grystin Djein Sumilat, I am associated with Universitas Negeri Manado Tondano Indonesia my area of interest is social science. 